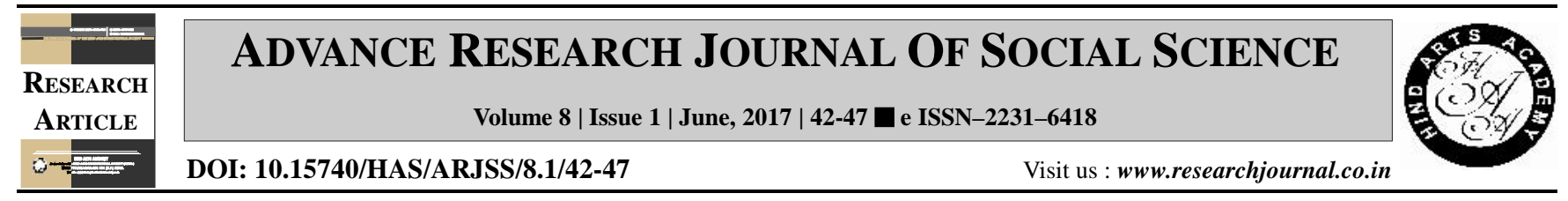

\title{
Self-concept and academic achievement of rural school going children engaged in agricultural activities : A correlational study
}

Simarjeet Kaur* and Sukhminder Kaur

Department of Human Development and Family Studies, Punjab Agricultural University, LUDHIANA (PUNJAB) INDIA

(Email: simargillpau@gmail.com; sukhminder@pau.edu)

\section{ARTICLE INFO :}

$\begin{array}{lll}\text { Received } & : & 16.03 .2017 \\ \text { Revised } & : & 15.04 .2017 \\ \text { Accepted } & : & 01.05 .2017\end{array}$

KEY WORDS :

Academic achievement, Agriculture, Children, Self-concept

HOW TO CITE THIS ARTICLE :

Kaur, Simarjeet and Kaur, Sukhminder (2017). Self-concept and academic achievement of rural school going children engaged in agricultural activities : A correlational study. Adv. Res. J. Soc. Sci., 8 (1) : 42-47, DOI: 10.15740/HAS/ ARJSS/8.1/42-47.

*Author for correspondence

\begin{abstract}
The present study was undertaken on rural school going children engaged in agricultural labour with the objectives to determine the self-concept of the children and find out the relationship of self-concept with the academic achievement of the children. The sample consisted of 160 children (both boys and girls) in the age range of 10-14 years. The tools used to collect the data were; Personal Information Sheet to record the demographic profile of the children, a self-concept inventory developed by Saraswat (1992) to determine the self-concept of the children and the information relating to academic achievement was obtained from school records. The results revealed that self-concept of girls was found to be higher as compared to the boys and it was found to be positively correlated with the academic achievement. The total self-concept of both boys and girls was found to be positively correlated with academic achievement. The correlation was found to be highly positively significant for both girls ( $\mathrm{r}$-value= $0.71 ; \mathrm{P}<0.01)$ and boys ( $\mathrm{r}$-value $=0.68 ; \mathrm{P}<0.01$ ). Highly significant differences were observed among girls and boys on various dimensions of self concept such as social, educational, moral and intellectual.
\end{abstract}

